HELMINTHOLOGIA, 55, 2: 146 - 156, 2018

\title{
The diversity of teleost fish trematodes in the Bay of Bizerte, Tunisia (Western Mediterranean)
}

\author{
R. ANTAR*, L. GARGOURI
}

Unité de Recherche: Bio-Ecologie Animale et Systématique Evolutive, Faculté des Sciences, Université Tunis El Manar, 2092 Tunis, Tunisie, *E-mail: rym.antar@hotmail.fr

\section{Article info}

Received December 5, 2017 Accepted January 16, 2018

\begin{abstract}
Summary
A total of 39 digeneans species allocated to 28 genera in 12 families were recovered from 534 fishes belonging to 14 species in three families (Carangidae, Mullidae and Sparidae) collected in the Bay of Bizerte off the coast of Tunisia. We provide a host-parasite list of records from this locality, including 63 host-parasite combinations. The Opecoelidae Ozaki, 1925 is the most diverse group with 12 species. The species richness of individual digenean genera in the Bay of Bizerte ranges from $1-6$ species. The mean number of 2.58 species per host indicates a relatively high digenean diversity in the Bay of Bizerte, which is related to its geographical location, its connection with the neighbouring Bizerte Lagoon and the nature of the bottoms of the littoral marine areas off the northern Tunisian coasts. This diversity is significantly higher than that reported off the southern coast of Tunisia and distinctly lower than that observed for teleost hosts in the Scandola Nature Reserve off Corsica. Generally, the levels of infection in teleosts fishes from the Bay of Bizerte are lower than those from the other two localities.
\end{abstract}

Keywords: Digenea; diversity; checklist; Bay of Bizerte; Mediterranean; Tunisia

\section{Introduction}

Parasites of aquatic organisms constitute an essential part of aquatic ecosystems. The evaluation of parasite biodiversity and the monitoring of community dynamics may constitute a good indicator of potential changes that might affect these ecosystems. These parasites include digeneans that often depend on trophic interactions for their transmission. Moreover, due to their complex life-cycles that require two or more intermediate hosts, digenean trematode parasites are linked to several different taxa and constitute excellent bioindicators of biodiversity (Marcogliese \& Cone, 1997a, b; Hechinger et al., 2007). Positive correlations have been demonstrated between the digenean species richness and faunistic diversity (Hechinger \& Lafferty, 2005; Hechinger et al., 2007). In the Mediterranean region, numerous studies, starting in the 19th
Century, have been conducted on digenean species parasitic in fish. As a result, a total of 303 species has been reported and described from just 192 fish species (Pérez-del-Olmo et al., 2016; Rima et al., 2017). In contrast, in Tunisia, interest in these helminths has been developed only over the past 20 years with the pioneer studies of Gargouri Ben Abdallah and Maamouri (1997, 2002, 2005a, b, 2008) and Gargouri Ben Abdallah et al. (2010) on the diversity and the life-cycles of fish digeneans off the northern coast of the country. In 2012, another determined effort was made by Derbel and co-workers to contribute to our knowledge of the digenean fauna in marine fishes off the southeastern coast of Tunisia (Derbel et al., 2012). In an earlier study on the biodiversity of digeneans in the Bizerte Lagoon (an inlet of the Mediterranean in northeastern Tunisia), we reported 30 species of digeneans from sparid fishes (Gargouri Ben Abdallah et al., 2011; Antar \& Gar-

\footnotetext{
* - corresponding author
} 
gouri, 2013; Antar et al., 2015). Of these, two were recognised using both morphological and molecular methods (see Antar et al., 2015). In addition, the life cycle of Proctoeces maculatus (Looss, 1901) was studied in Bizerte Lagoon using the same methods, resulting in our suggesting the existence of cryptic species based on the different developmental stages of the life-cycle of this 'species' (Antar \& Gargouri, 2015). In the present work, we provide information on the diversity of digenean species in teleost fishes off the northern coast of Tunisia (Bay of Bizerte) and compare our results with those already published for the other localities of the Mediterranean Sea.

\section{Materials and Methods}

Over a 3-year sampling period (2010 - 2012), a total of 534 teleosts was collected from the Bay of Bizerte $\left(37^{\circ} 16^{\prime} 47.02^{\prime \prime} \mathrm{N}\right.$ $9^{\circ} 58^{\prime} 23.38$ "E) located off the northeastern coast of Tunisia. Fish were obtained fresh from local fishermen in the Bay of Bizerte, kept on ice and immediately brought back to the laboratory where they were identified based on Fischer et al. (1987), then measured, weighed, photographed and dissected. Fish names follow FishBase (Froese \& Pauly, 2016). The gastrointestinal tract was then removed and examined for digeneans under a binocular microscope; the worms recovered were fixed alive by being pipetted into near-boiling saline. Afterwards, they were stained with borax carmine, dehydrated through a graded ethanol series, cleared in clove oil (eugenol) and examined as permanent mounts in Canada balsam. Several live specimens were examined for identification as temporary mounts in cold saline under the slight pressure of a coverslip. Ecological terms (prevalence, abundance and mean intensity) follow the definitions of Margolis et al. (1982).

\section{Ethical Approval and/or Informed Consent}

All applicable institutional, national and international guidelines for the care and use of animals were followed.

\section{Results}

A total of 39 digenean species allocated to 28 genera in 12 families were recovered from 534 fishes belonging to 14 different species from 12 genera in three families. Most of them were found in members of the Sparidae. We identified 63 host-parasite combinations (Table 1). The most species rich digenean family, the Opecoelidae Ozaki, 1925 (with 12 species), accounted for $30.8 \%$ of the total species and included six species of Macvicaria Gibson and Bray, 1980, among which was M. bartolii Antar, Georgieva, Gargouri and Kostadinova, 2015, a species recently described using both morphology and molecular information from ITS1-5.8S-ITS2 sequences and partial sequences of the 28S rRNA gene (Antar et al., 2015), and one species each of Allopodocotylle Pritchard, 1966, Opecoeloides Odhner, 1928, Pachycreadium Manter, 1954, Pora- canthium Dollfus, 1948, Pseudopycnadena Saad Fares and Maillard, 1986 and Pycnadenoides Yamaguti, 1938. The Opecoelidae is also the most diverse digenean family in the Mediterranean, with 42 species (Pérez-del-Olmo et al., 2016; Rima et al., 2017). The species richness of individual genera in the Bay of Bizerte ranged from 1 - 6 species, although most genera $(78.6 \%)$ have only a single species, which accounts for 22 of the digenean species. These genera exploit three infected fish families (Carangidae, Mullidae and Sparidae). After Macvicaria, Holorchis Stossich 1901 is the next most species rich genus, with three species.

Of the 14 teleost species examined, only Pomatomus saltatrix (Linnaeus, 1766) lacked digenean parasites. Two digenean species have been reported from this host in the Black Sea and off the southern coast of Tunisia (Opechona bacillaris (Molin, 1859) (see Bray \& Gibson, 1990) and Prosorhynchoides arcuatus (Linton, 1900) (see Derbel et al., 2012)). The absence of digeneans in $P$. saltatrix in the Bay of Bizerte can be explained by the low numbers of this host examined due to its scarcity in the study area, its biological and ecological preferences and also by its small body size; the three specimens examined were all young. Several authors have highlighted the relationship between host body size and the number of parasites and their composition (Grutter \& Poulin, 1998; Lo et al., 1998; Muñoz et al., 2002; Muñoz \& Cribb, 2005, 2006). They concluded that larger host individuals had a higher species richness of parasites than smaller individuals. Indeed, resources are more important and microhabitats are more varied in a large rather than a small body (Muñoz et al., 2002; Muñoz \& Cribb, 2005). The highest species richness was recorded in the sparid Diplodus sargus sargus (Linnaeus, 1758), with nine species (28\% of all species recorded in this study), followed by Boops boops (Linnaeus, 1758) and Pagellus erythrinus (Linnaeus, 1758), each with 7 species $(21.9 \%)$. The digenean faunas of these three fish species were dominated by Macvicaria crassigula (Linton, 1910), Aphanurus stossichii (Monticelli, 1891) and Holorchis pycnoporus Stossich, 1901, respectively. Sarpa salpa (Linnaeus, 1758) and Sparus aurata Linnaeus, 1758 each harboured six species (18.7\%), whereas Mullus surmeletus Linneaus, 1758 was infected with five trematode species (15.6\%). Diplodus vulgaris (Geoffroy St.-Hilaire, 1817) and Pagrus pagrus (Linnaeus, 1758) exhibited a lower diversity, not exceeding four digenean species (12.5\%). Five host species (9.4\%) (Diplodus annularis (Linnaeus, 1758), Lithognathus mormyrus (Linnaeus, 1758), Oblada melanura (Linnaeus, 1758), Trachurus trachurus (Linnaeus, 1758) and Spondyliosoma cantharus (Linnaeus, 1758)) were infected with three digenean species.

Examination of the parasitological descriptors of species richness (Margolis et al., 1982; Valtonen et al., 1997) shows that several species (e.g. Arnola microcirrus (Vlasenko, 1931), Holorchis legendrei Dollfus, 1946, Macvicaria mormyri (Stossich, 1885), Magnibursatus bartolii Kostadinova, Power, Fernández, Balbuena, Raga and Gibson, 2003, Pycnadenoides senegalensis Fischthal and Thomas, 1972, Poracanthium furcatum Dollfus, 


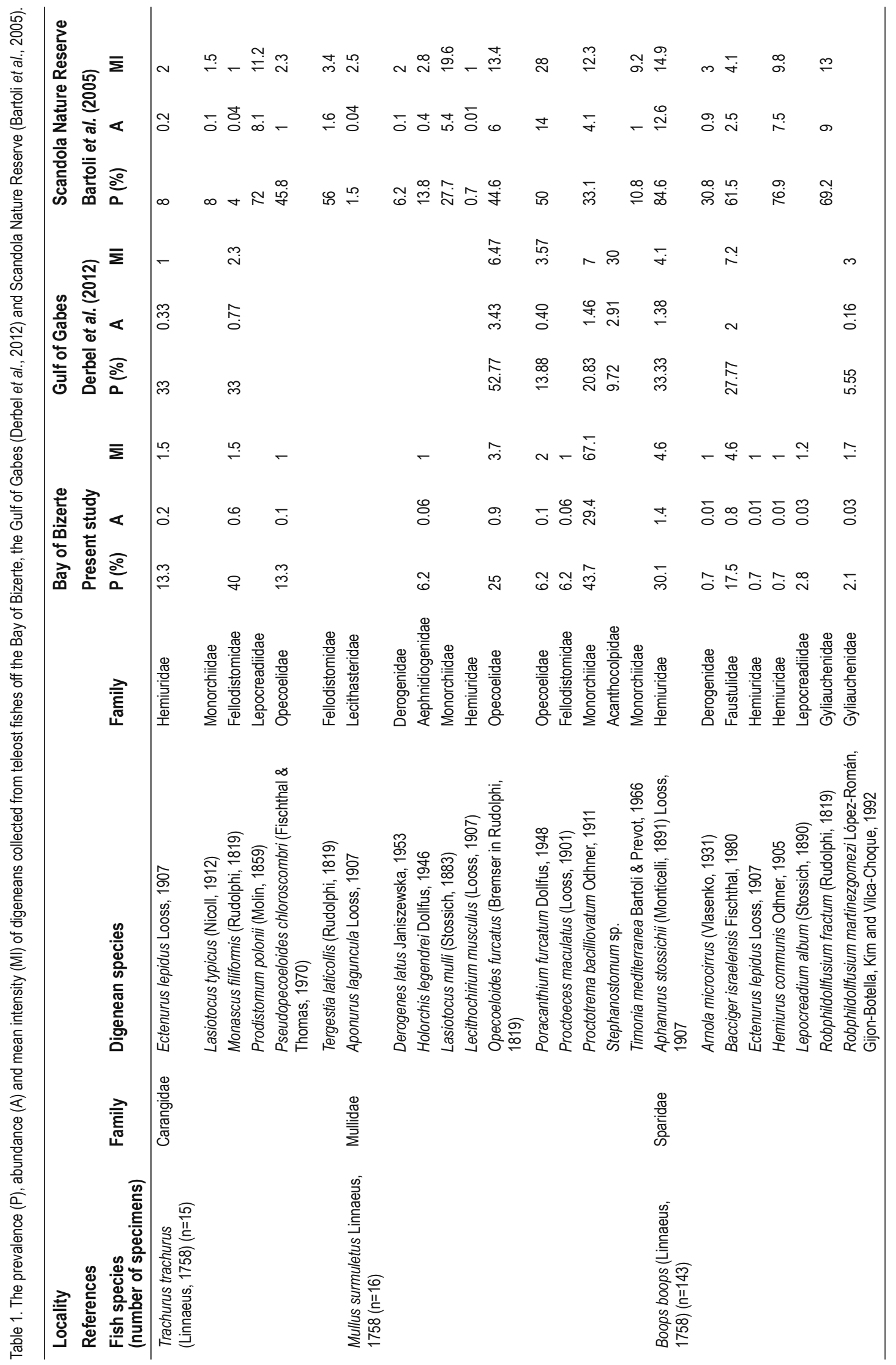




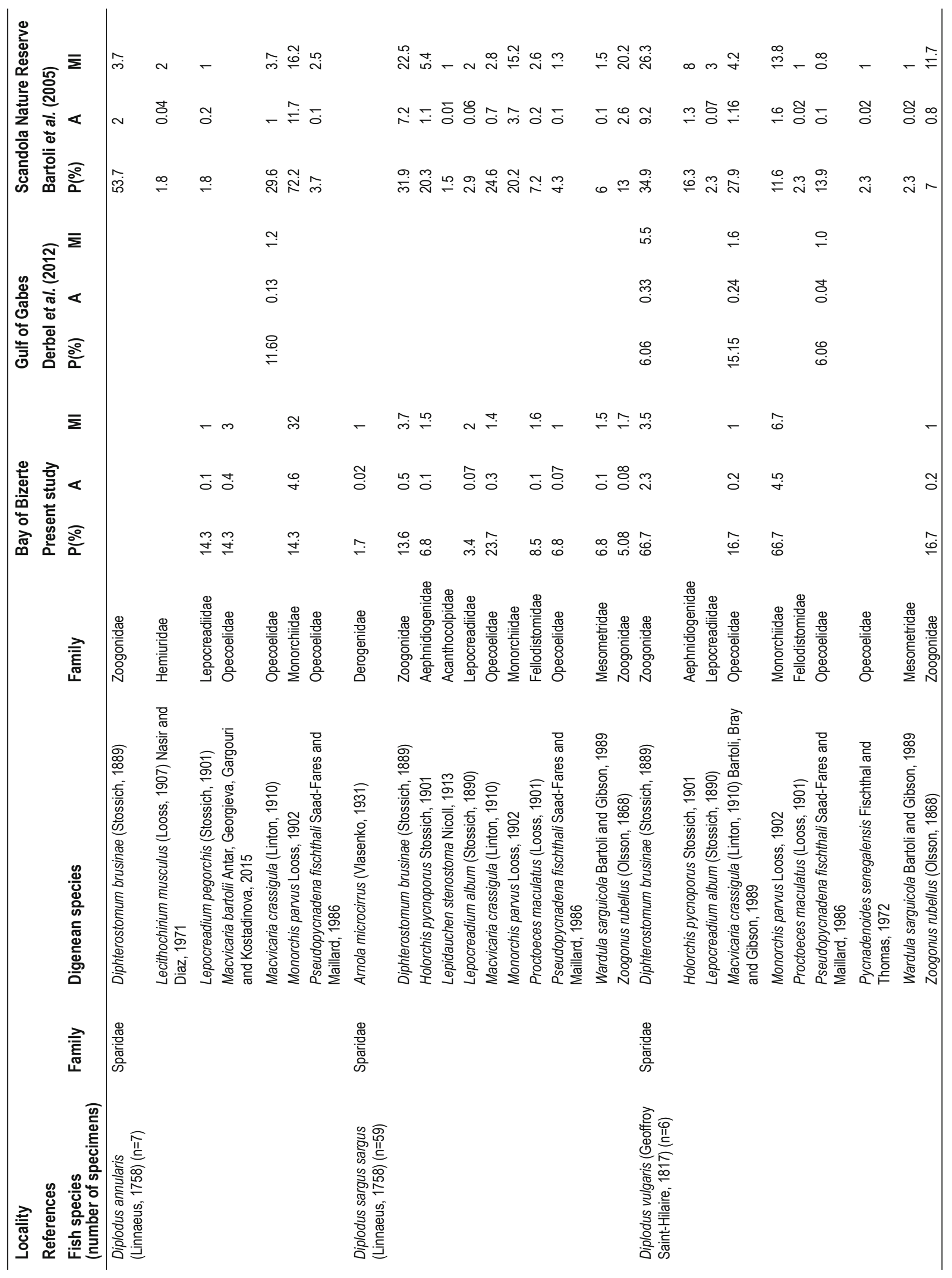




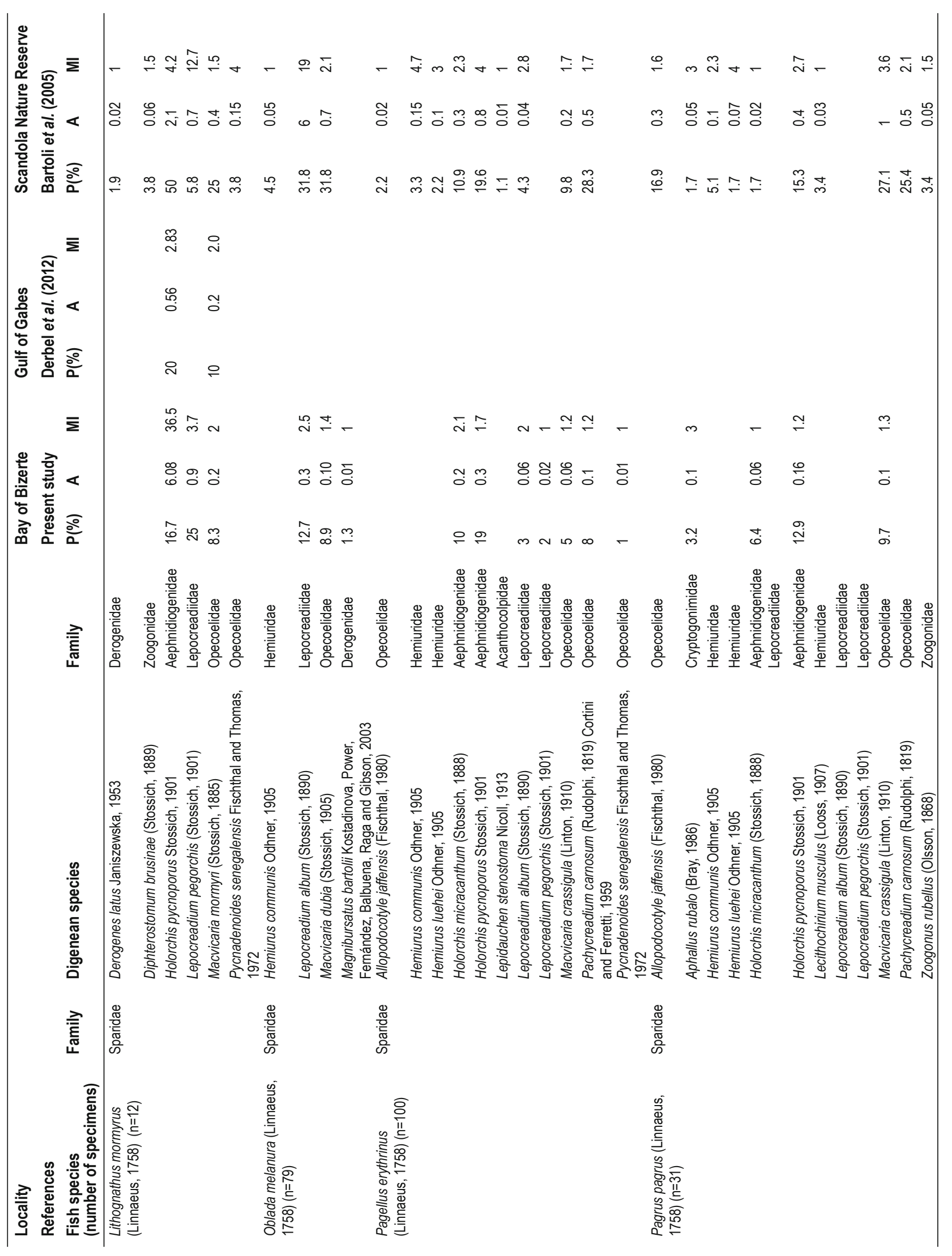




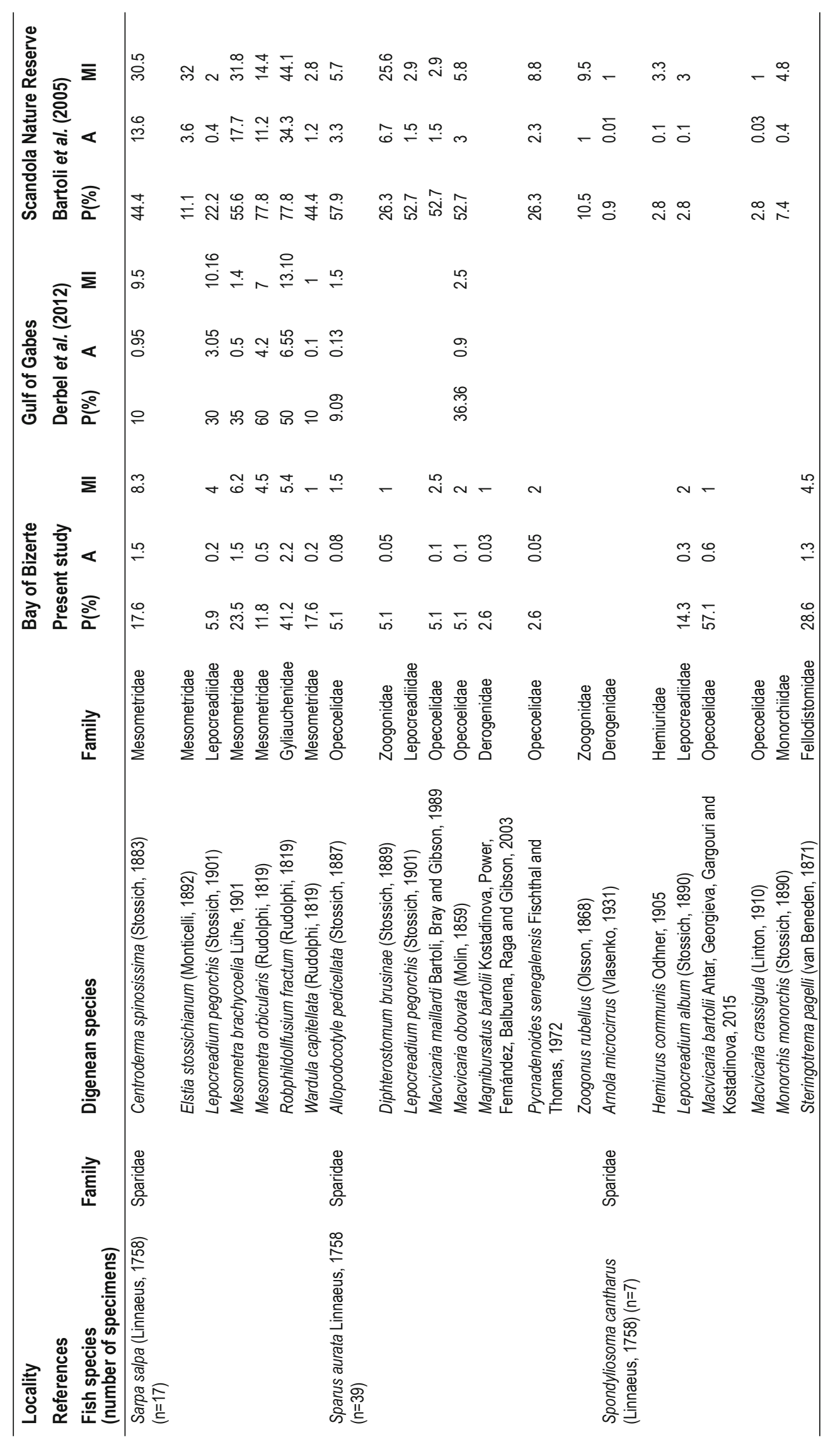


1948 and Robphildollfusium martinezgomezi López-Román, Gijon-Botella, Kim and Vilca-Choque, 1992) are considered rare (prevalence < $10 \%$ ). Some species (e.g. Aphanurus stossichii, Bacciger israelensis Fischthal, 1980, Monascus filiformis (Rudolphi, 1819), Opecoeloides furcatus (Bremser in Rudolphi, 1819) and Proctotrema bacilliovatum Odhner, 1911) exhibit a higher level prevalence $(10-50 \%)$ and are considered as intermediate species. Some others can be rare, intermediate or common (prevalence $>50 \%$ ), depending on the host species; for example, this is the case for Diphterostomum brusinae (Stossich, 1889), Ectenurus lepidus Looss, 1907, Holorchis micracanthum (Stossich, 1888), H. pycnoporus, Lepocreadium pegorchis (Stossich, 1901) and Macvicaria bartolii. Such a variation is undoubtedly related to the presence of preferred host species.

The majority of digeneans in the Bay of Bizerte ( 26 species = $66.7 \%$ ) parasitize a single host species, eight were found in two host species and three were collected from four host species. $D$. brusinae and Lepocreadium album (Stossich, 1890) were recovered from three and five host species, respectively. The mean number of hosts per species is 1.61. In the light of these results, the overwhelming pattern of host-specificity in the Bay of Bizerte seems to be high. However, despite the availability of the other potential hosts, some species, such as Aphallus rubalo (Bray, 1986), Aphanurus stossichii, Hemiurus communis Odhner, 1905, Pachycreadium carnosum (Rudolphi, 1819), Pseudopycnadena fischthali Saad-Fares and Maillard, 1986 and Wardula sarguicola Bartoli and Gibson, 1989, infect a single host species in the Bay of Bizerte, whereas they are known to have no strict host-specificity in the Mediterranean region (Sasal et al., 1999; Bartoli et al., 2005). Previous studies have shown that the variety in the diet of a host species, its vagility, its relatedness to other sympatric host species and how long it has been in the area can influence the chances of a host acquiring parasite species (Price \& Clancy, 1983; Kennedy et al., 1986; Kennedy \& Bush, 1994). It is notable that $E$. lepidus, a common parasite of a wide range of marine teleosts (Atherinidae, Carangidae, Sparidae, Lophiidae, Scombridae) was recovered from only two hosts, $B$. boops and $T$. trachurus, in the Bay of Bizerte; the former is a new host record for this digenean. We admit that further sampling of a broad range of fish families may well change our understanding of the patterns of host-specificity in the Bay of Bizerte.

\section{Discussion}

The mean number of 2.58 species per host, estimated from published data on digenean parasites of labrid fish from the Bay of Bizerte (Gargouri et al., 2010) and the present study, is distinctly lower than that reported for teleost hosts in the Scandola Nature Reserve off Corsica (3.8, see Bartoli et al., 2005) and significantly higher than that observed for teleosts off the southern coast of Tunisia (1.7, see Derbel et al., 2012). Bartoli and co-workers (2005) reported for different basins of the Mediterranean a range of mean values $(0.6-2.9$ species per host). The comparison of our data and these reports shows similar digenean species richness to that in teleosts from Eastern Mediterranean and a greater digenean diversity than that reported in teleosts from the Adriatic and north-western Italian coast (see Bartoli et al., 2005). Furthermore, in a recent study of the trematode fauna of the Mediterranean, Pérez-del-Olmo et al. (2016) estimated a lower overall mean number (1.57 species per host) indicating, according to these authors, a high diversity in the Mediterranean. However, these authors stated that they did not consider geographical variation in terms of faunal richness and that their estimate was rather artificial. Similar results were obtained when we, taking into account the work carried out by Gargouri et al. (2010), compared the data reported for the same 10 teleost species studied in the Bay of Bizerte, the Gulf of Gabes and the Scandola Nature Reserve. An intermediate situation for the Bay of Bizerte was encountered, with a mean number of 3.8 species per host, which is much higher than that for the southern coast of Tunisia (2.1 species per host) and lower than that for the Scandola Nature Reserve (4.2 species per host). The environment at the Bay of Bizerte appears to provide favourable conditions for the transmission of digeneans and the completion of their life-cycles. Among the possible reasons explaining the relatively high digenean diversity in teleosts from the Bay of Bizerte is its situation in the eastern part of the Western Mediterranean (FAO division 37.1.3 Sardinia) and its connection with the neighbouring Mediterranean lagoon, i.e. Bizerte Lagoon, via a channel. Indeed, several studies (Bartoli, 1974; Maillard, 1976; Thomas et al., 1997; Bartoli \& Gibson, 2007) have pointed out the importance of parasitism in lagoonal ecosystems; these shallow and confined biotopes with high specific diversity and high predation levels favour the life-cycles and the transmission of parasites. Moreover, Saad Fares (1985) attributed the low digenean diversity observed off the Lebanese coasts to obstacles to the completion of the life-cycle of parasites on these coasts, which are characterized by the absence of lagoons and ponds. On the other hand, the north coast of Tunisia presents a varied topography. In fact, the substrata are mainly rocky but also both hard and soft; this variety of biotopes enables a high biodiversity (Boudouresque, 1997). The mainly rocky bottoms of the littoral marine areas of the northern Tunisian coasts offer the best substrata for the colonization of very rich, coralligenous assemblages (Ben Mustapha et al., 2002). Posidonia oceanica meadows are also well represented in this part of the Tunisian coast and are geographically extensive off Bizerte and Cani (Ben Mustapha et al., 2002). Both biocoenoses exhibit a high diversity of macro-benthic organisms (Ben Mustapha et al., 2002), some of which act as intermediate hosts for several digeneans species. In addition, Posidonia oceanica meadows represent productive ecosystems that provide habitats and food resources for a diverse fish fauna and act as important nursery areas for many coastal species (Harmelin-Vivien, 1982). Also, due to the nature of the sea bottom off the northern region of Tunisia, some fishing methods, such as bottom trawling, are not practiced. Bottom trawling is considered 
one of the most disruptive human-induced physical disturbances to seabed communities (Rumohr \& Krost, 1991). Indeed, previous studies have shown that the biomass and abundance of benthic organisms is reduced by trawling, leading to long-term changes in the benthic species composition (Reise, 1982; Reise \& Schubert, 1987; Thrush et al., 1991). Engel \& Kvitek (1998) provided evidence that high levels of trawling can decrease bottom habitat complexity and biodiversity. Derbel et al. (2012) attributed the low digenean richness in the Gulf of Gabes to the disturbance resulting from changes in the structure and the function of the marine ecosystem off southern Tunisia caused by human activities (overfishing and the use of the trawling) and the impact of exotic species (the introduction of invasive algae). Conversely, the high digenean diversity reported for the Scandola Nature Reserve is related to its high general level of biodiversity (Miniconi et al., 1990; Verlaque, 1990; Verlaque et al., 1999) and related to the stability of the equilibrium of the ecosystem, which has been strictly protected since 1979 and where spear-fishing and angling are prohibited.

Examination of the level of infection revealed that digeneans, in general, exhibited a higher prevalence in the Scandola Nature Reserve and Gulf of Gabes than in the Bay of Bizerte. There are many reasons which might explain the origin of this differential distribution of digenean frequencies between the different Mediterranean environments. The high level of prevalence reported for the Gulf of Gabes appears to be related to a greater sampling effort (534 teleosts of 14 species for the Bay of Bizerte vs 779 teleosts of 32 species for the Gulf of Gabes) and to the abundance of intermediate hosts, and in particular the molluscan host, in this locality. Furthermore, during their free-living phases, parasites of aquatic organisms with complex life-cycles are negatively affected by changes of environmental conditions, including urban and industrial pollution and other anthropogenic perturbations (Pietrock \& Marcogliese, 2003). They are sensitive to environmental stressors such as wastewater or industrial pollutants and chemicals released into the environment as a result of human activities and their transmission is impeded or modified in polluted habitats (MacKenzie et al., 1995; Marcogliese \& Cone, 1997). These pollutants are toxic and lead to a decrease in the prevalence and abundance of parasites by acting directly on the parasites themselves and their free-living stages, or indirectly on density of the definitive or intermediate hosts (Overstreet \& Howse, 1977; Khan \& Thulin, 1991; Poulin, 1992; MacKenzie et al., 1995; Lafferty, 1997; Sures, 2004, 2008). According to MacKenzie et al. (1995), pollutants may influence the infection levels of endohelminths in fish hosts by affecting the numbers of parasite larval stages carried by invertebrate intermediate hosts or by causing changes in the pathogenicity of invertebrate pathogens. In the Bay of Bizerte, the major source of pollution is a large oil refinery. This refinery has, since 1999, imported all of Tunisia's requirements for petroleum products, and its potential as a direct source of oil pollution has been accentuated by an increasing production of refined products. Indeed, a simple direct observation has revealed the non-negligi- ble presence of hydrocarbons in the wastewater of this refinery released into the marine environment (Boufahja, 2010). Moreover, oil traffic can also, even accidentally, result in the discharge of crude or refined petroleum products during load shedding or pumping operations (Beyrem, 1999). Some laboratory experiments and studies of wild-caught fish suggest that exposure to oil and its components reduces the prevalence and intensity of gastrointestinal helminths (Haensly et al., 1982; Kiceniuk \& Khan, 1983). Furthermore, Khan and Kiceniuk (1983) have suggested that the low species diversity and the low infection intensity of gut parasites in fish exposed to oil might be attributed to its toxicity acting directly on the parasites and/or causing a modification of the gut environment which becomes inhospitable to the parasites; the latter is brought about by changes in fish physiology. On the other hand, the invasive seaweed Caulerpa taxifolia, reported for the first time in Tunisian waters by Langar et al. (2000), synthesizes toxic metabolites which are released into the environment. These metabolites can affect the behaviour, survival and transmission of infective, free-living, larval stages to the intermediate hosts (Bartoli \& Boudouresque, 1997). Digenean free-living stages are also sensitive to the action of exogenous environmental factors, such as temperature, salinity, hydrogen ion concentration, water level and photoperiod. The variation of these abiotic factors influences the prevalence of parasites and their presence in both time and space (Chubb, 1979, 1980) by affecting the rates of cercarial emergence and the transmission success.

In conclusion, our comparative study showed a high diversity of digenean species in teleost fishes off the northern coast of Tunisia suggesting that the Bay of Bizerte provide favourable conditions for the transmission of these helminths and the completion of their life-cycles.

\section{Conflict of Interest}

The authors declare that they have no conflict of interest.

\section{Acknowledgements}

We are grateful to Dr Carlos Mendoza Palmero for his comments on the original manuscript.

\section{Funding}

This study was supported by the Tunisian Government, the Ministry of Higher Education and Scientific Research.

\section{References}

Antar, R., Gargouri Ben Abdallah, L. (2013): Trematodes in fishes of the genus Diplodus (Teleostei, Sparidae) from Bizerte Lagoon (Northern coast of Tunisia). Bull. Eur. Assoc. Fish Pathol., 33: 44 $-52$ 
AntAR, R., GARgouRI, L. (2015): Morphology and molecular analysis of life-cycle stages of Proctoeces maculatus (Looss, 1901) (Digenea: Fellodistomidae) in the Bizerte Lagoon, Tunisia. J. Helminthol., 90: 726 - 736. DOI: 10.1017/S0022149X15001030

Antar, R., Georgieva, S., Gargouri, L., Kostadinova, A. (2015): Molecular evidence for the existence of species complexes within Macvicaria Gibson \& Bray, 1982 (Digenea: Opecoelidae) in the western Mediterranean, with descriptions of two new species. Syst. Parasitol., 91: 211 - 229. DOI: 10.1007/s11230-015-9577-9 BARTOLI, P. (1974): Recherches sur les Gymnophallidae F.N. Morozov, 1955 (Digenea), parasites d'oiseaux des côtes de Camargue : systématique, biologie et écologie [Research on Gymnophallidae F.N. Morozov, 1955 (Digenea), parasites of birds of coasts of Camargue: systematic, biology and ecology]. PhD thesis, Marseille, France: Université Paul Cézanne (In French)

Bartoli, P., Boudouresque, C.F. (1997): Transmission of parasites (Digenea) in sites colonized by the recently introduced invasive alga Caulerpa taxifolia. Mar. Ecol. Prog. Ser., 154: 253 - 260. DOI: 10.3354/meps154253

Bartoli, P., GibSON, D.I. (2007): Synopsis of the life cycles of Digenea (Platyhelminthes) from lagoons of the northern coast of the Western Mediterranean. J. Nat. Hist., 41:1553 - 1570. DOI: 10.1080/00222930701500142

Bartoli, P., Gibson, D.I., Bray, R.A. (2005): Digenean species diversity in teleost fish from a nature reserve off Corsica, France (Western Mediterranean), and a comparison with other Mediterranean regions. J. Nat. Hist., 391: 47 - 70. DOI: 10.1080/00222930310001613557

Ben Mustapha, K., Komatsu, T., Hattour, A., Sammari, Ch., Zarrouk, S., Souissi, A., El Abed, A. (2002): Tunisian mega benthos from infra (Posidonia medows) and circalittoral (Coralligenous) sites. Bull. Inst. Natn. Sci. Tech. Mer de Salammbô, 29: 23 - 36.

BeYRem, H. (1999):Ecologie des nématodes libres de deux milieux anthropiquement perturbés: la baie de Bizerte et le lac Ichkeul [Ecology of free nematodes from two anthropically disturbed environments: Bizerte Bay and Lake Ichkeul]. PhD thesis, Bizerte, Tunisie: Faculté des Sciences de Bizerte (In French)

BraY, R.A., GiBSON, D.I. (1990): The Lepocreadiidae (Digenea) of fishes of the north-east Atlantic: review of the genera Opechona Looss, 1907 and Prodistomum Linton, 1910. Syst. Parasitol., 15: 159 - 202. DOI: $10.1007 / B F 00010135$

BOUDOURESQUE, C.F. (1997): Situation de la biodiversité marine et lagunaire en Tunisie. Recommandations [Situation of marine and lagoonal biodiversity in Tunisia. Recommendations]. CAR/ASP Tunis et GIS Posidonie Publications, France, 154pp. (In French) BOUFAHJA, F. (2010): Approches communautaires et populationnelles de biosurveillance du milieu marin chez les nématodes libres (lagune et baie de Bizerte, Tunisie) [Community and population approaches to marine biomonitoring in free-living nematodes (Lagoon and Bizerte Bay, Tunisia)]. PhD thesis, Bizerte, Tunisie: Faculté des Sciences de Bizerte (In French)

CHubB, J.C. (1979): Seasonal occurrence of helminths in freshwa- ter fishes. Part II. Trematoda. Adv. Parasitol., 17: 141 - 313. DOI: 10.1016/S0065-308X(08)60551-5

CHuBB, J.C. (1980): Seasonal occurrence of helminths in freshwater fishes. Part III. Larval cestoda and nematoda. Adv. Parasitol., 18: 1 - 120. DOI: 10.1016/S0065-308X(08)60398-X

Derbel, H., ChÂARI, M., Neifar, L. (2012): Digenean species diversity in teleost fishes from the Gulf of Gabes, Tunisia (Western Mediterranean). Parasite, 19: 129 - 135. DOI: 10.1051/parasite/2012192129

ENGEL, J., KVITEK, R. (1998): Effects of otter trawling on a benthic community in Monterey Bay national marine sanctuary. Conserv. Biol., 12: 1204 - 1214

Fischer, W., Seneider, M., Bauchaut, M.L. (1987): Fiches FaO d'identification des espèces pour les besoins de la pêche. Méditerranée et Mer noire. Zone de pêche 37. Volume 2 Vertébrés [FAO species identification sheets for fishery purposes. Mediterranean and Black Sea. Fishing area 37. Volume 2 Vertebrates]. FAO, Rome, 1529pp. (In French)

Froese, R., Pauly, D. (2016): FishBase. World Wide Web electronic publication. Retrieved November 15, 2016 from www.fishbase.org. Gargouri Ben Abdallah, L., Maamouri, F. (1997): Evolution du parasitisme chez le Muge Mugil cephalus dans trois lacs de la Tunisie [Evolution of parasitism in the flathead grey mullet Mugil cephalus in three lakes of Tunisia]. Ichtyophysiol. acta, 20: 177 - 180 (In French)

Gargouri Ben Abdallah, L., Maamouri, F. (2002): Cycle évolutif de Bucephalus anguillae Spakulova, Macko, Berrilli \& Dezfuli, 2002 (Digenea, Bucephalidae) parasite de Anguilla anguilla (L.) [Life cycle of Bucephalus anguillae Spakulova, Macko, Berrilli \& Dezfuli, 2002 (Digenea, Bucephalidae) parasite of Anguilla anguilla (L.)]. Syst. Parasitol., 53(3): 207 - 217. DOI: 10.1023/A:1021163528452 (In French)

Gargouri Ben Abdallah, L., Maamouri, F. (2005a): Dynamique évolutive des communautés des digènes parasites de Anguilla anguilla dans les lagunes du nord est de la Tunisie [Evolutionary dynamic of digenea communities in Anguilla anguilla from the north tunisian lagoons]. Bull. Soc. Zool. Fr., 130: 95 - 106 (In French) Gargouri Ben Abdallah, L., Maamourl, F. (2005b): The life cycle of Bucephalus labracis (Paggi and Orecchia, 1965) parasite of Dicentrarchus labrax. Bull. Eur. Assoc. Fish Pathol., 25: 297 - 301

Gargouri Ben Abdallah, L., Maamouri, F. (2008): Digenean fauna diversity in Sparid fish from Tunisian coasts. Bull. Eur. Assoc. Fish Pathol., 28: 129 - 137

Gargouri Ben Abdallah, L., Elbohl, S., Maamouri, F. (2010): Digenean diversity in labrid fish from the Bay of Bizerte in Tunisia. J. Helminthol., 84: 27 - 33. DOI: 10.1017/S0022149X09990022

Gargouri Ben Abdallah, L., Antar, R., Maamouri, F. (2011): Diversity of the digenean fauna in sparid fishes from the Lagoon of Bizerte in Tunisia. Acta Parasitol., 56: 34 - 39. DOI: 10.2478/s11686-0110007-0

Grutter, A.S., Poulin, R. (1998): Intraspecific and interspecific relationships between host size and the abundance of parasitic 
larval gnathiid isopods on coral reef fishes. Mar. Ecol. Prog. Ser., 164: 263 - 271. DOI: 10.1111/j.1365-2761.1982.tb00494.x

Haensly, W.E., Neff, J.M., Sharp, J.R., Morris, A.C., Bedgood, M.F., Boem, P.D. (1982): Histopathology of Pleuronectes platessa L. from Aber Wrac'h and Aber Benoit, Brittany, France: long-term effects of the Amoco Cadiz crude oil spill. J. Fish Dis., 5: 365 391. DOI: 10.1111/j.1365-2761.1982.tb00494.x

HaRmelin-VIVIEN, M. (1982): Ichtyofaune des herbiers de Posidonia oceanica du parc national de Port-Cros: I. composition et variation temporelle [Ichthyofauna of the Posidonia oceanica meadows of the Port-Cros National Park: I. Composition and temporal variation]. Trav. Sci. Parc Natl. Port-Cros., 8: 69 - 92 (In French)

HeCHINGER, R.F., LAFFERTY, K.D. (2005): Host diversity begets parasite diversity: bird final hosts and trematodes in snail intermediate hosts. Proc. R. Soc. B, 272: 1059 - 1066. DOI:10.1098/ rspb.2005.3070

HeChinger, R.F., LafFerty, K.D., Huspeni, T.C., BRoOKs, A.J., KuRIS, A.M. (2007): Can parasites be indicators of free-living diversity? Relationships between species richness and the abundance of larval trematodes and of local benthos and fishes. Oecologia, 151: 82 - 92. DOI: 10.1007/s00442-006-0568-z

KeNNEDY, C.R., Bush, A.O. (1994): The relationship between pattern and scale in parasite communities: a stranger in a strange land. Parasitology, 109: 187 - 196. DOI: 10.1017/S0031182000076290 Kennedy, C.R., Bush, A.O., Aно, J.M. (1986): Patterns in helminth communities: why are birds and fish different? Parasitology, 93: 205 - 215. DOI: 10.1017/S0031182000049945

KHAN, R.A., KICENIUK, J. (1983): Effects of crude oil on the gastrointestinal parasites of two species of marine fish. J. Wildl. Dis., 19: 253 - 258. DOI: 10.7589/0090-3558-19.3.253

KHAN, R.A., Thulin, J. (1991): Influence of pollution on parasites of aquatic animals. Adv. Parasitol., 30: 201 - 238. DOI: 10.1016/ S0065-308X(08)60309-7

KiceniuK, J., Khan, R.A. (1983): Toxicology of chronic crude oil exposure: sublethal effects on aquatic organisms. In: NRAIGU, J.O. (Ed.) Aquatic Toxicology. John Wiley, New York, pp.425 - 536

LAFFERTY, K.D. (1997): Environmental parasitology: what can parasites tell us about human impact on the environment? Parasitol. Today, 13: 251 - 255. DOI: 10.1016/S0169-4758(97)01072-7

Langar, H., Duallouli, A., Ben Mustapha, K., El Abed, A. (2000): Première signalisation de Caulerpa taxifolia (Vahl) J. Agardh, en Tunisie [First report of Caulerpa taxifolia (Vahl) J. Agardh in Tunisia]. Bull. Inst. Natn. Sci. Tech. Mer de Salammbô, 28: 3 - 8 (In French)

Lo, C.M., Morand, S., Galzin, R. (1998): Parasite diversity/host age and size relationship in three coral-reef fishes from French Polynesia. Int. J. Parasitol., 28: 1695 - 1708. DOI: 10.1016/S00207519(98)00140-4

MacKenzie, K., Williams, H.H., Williams, B., McVicar, A.H., Siddall, R. (1995): Parasites as indicators of water quality and the potential use of helminth transmission in marine pollution studies. $A d v$. Parasitol., 35: 85 - 144. DOI: 10.1016/S0065-308X(08)60070-6
MaIlLARD, C. (1976): Distomatoses de poissons en milieu lagunaire [Distomatosis of fish in lagoon environment]. PhD thesis, Montpellier, France: Université des Sciences et Techniques du Languedoc, 383 pp. (In French)

Marcogliese, D.J., Cone, D.K. (1997a): Food webs: a plea for parasites. Trends Ecol. Evol., 12: 320 - 325. DOI: 10.1016/S01695347(97)01080-X

Marcogliese, D.J., Cone, D.K. (1997b): Parasite communities as indicators of ecosystem stress. Parassitologia, 39: 227 - 232

Margolis, L., Esch, G.W., Holmes, J.C., KurIS, A.M., Schad, G.A. (1982): The use of ecological terms in parasitology (Report of an ad hoc committee of the American Society of Parasitologists). J. Parasitol., 68: 131 - 133. DOI: 10.2307/3281335

Miniconi, R., Francour, P., Bianconi, C.H. (1990): Inventaire de la faune ichthyologique de la Reserve Naturelle de Scandola (Corse, Méditerraneé nord-occidentale) [Inventory of the ichtyofauna of the marine park of Scandola (Corsica, North-Western Mediterranean)]. Cybium 14: 77 - 89 (In French)

MuÑOz, G., CRIBB, T.H. (2005): Infracommunity structure of parasites of Hemigymnus melapterus (Pisces: Labridae) from Lizard Island, Australia: the importance of habitat and parasite body size. J. Parasitol., 91 (1): 38 - 44. DOI: 10.1645/GE-3321

MuÑoz, G., CRIBB, T.H. (2006): Parasite communities and diet of Coris batuensis (Pisces: Labridae) from Lizard Island, Great Barrier Reef. Mem. Queensl. Mus., 52 (1): 191 - 198

Muñoz, G., Valdebenito, V., George-Nascimento, M. (2002): La dieta y la fauna de parásitos metazoos del torito Bovichthys chilensis Regan 1914 (Pisces: Bovichthydae) en la costa de Chile centro-sur: variaciones geográficas y ontogenéticas [Diet and metazoan parasite fauna of the thornfish Bovichthys chilensis Regan 1914 (Pisces: Bovichthydae) on the coast of central-south Chile: geographical and ontogenetic variations]. Rev. Chil. Hist. Nat., 75: 661 -671. DOI: 10.4067/S0716-078X2002000400003 (In Spanish) Overstreet, R.M., Howse, H.D. (1977): Some parasites and diseases of estuarine fishes in polluted habitats of Mississippi. Ann. N. Y. Acad. Sci., 298: 427 - 462. DOI: 10.1111/j.1749-6632.1977. tb19282.x

Pérez-del-Olmo, A., Kostadinova, A., Gibson, D.I. (2016): The Mediterranean: high discovery rates for a well-studied trematode fauna. Syst. Parasitol., 93: 249 - 256. DOI: 10.1007/s11230-016-9626-z Pietrock, M., Marcogliese, D.J. (2003): Free-living endohelminth stages: at the mercy of environmental conditions. Trends Parasitol., 19: 293 - 299. DOI: 10.1016/S1471-4922(03)00117-X

PoulIN, R. (1992): Toxic pollution and parasitism in freshwater fish. Parasitol. Today, 8: 58 - 61. DOI: 10.1016/0169-4758(92)90090-0 Price, P.W., Clancy, K.M. (1983): Patterns in number of helminth parasite species in freshwater fishes. J. Parasitol., 69: 449 - 454. DOI: $10.2307 / 3281352$

REISE, K. (1982): Long-term changes in the macrobenthic invertebrate fauna of the Wadden Sea: are polychaetes about to take over? Neth. J. Sea Res., 16: 26 - 36. DOI: 10.1016/00777579(82)90014-X 
Reise, K., Schubert, A. (1987): Macrobenthic turnover in the subtidal Wadden Sea: the Norderaue revisited after 60 years. Helgol. Mar. Res., 41(1): 69 - 82. DOI: 10.1007/BF02365100

Rima, M., Marzoug, D., Pérez-del-Olmo, A., Kostadinova, A., BouderbalA, M., Georgieva, S. (2017): New molecular and morphological data for opecoelid digeneans in two Mediterranean sparid fishes with descriptions of Macvicaria gibsoni n. sp. and M. crassigula (Linton, 1910) (sensu stricto). Syst. Parasitol., 94:739 - 763. DOI 10.1007/s11230-017-9736-2

RuMOHR, H., KROST, P. (1991): Experimental evidence of damage to benthos by bottom trawling with special reference to Arctica islandica. Meeresforsch., 33: 340 - 345

SAAD FAREs, A. (1985): Trématodes de poissons des côtes du Liban [Trematodes of fish from the shores of Lebanon]. PhD thesis, Montpellier, France: Université des Sciences et Techniques du Languedoc, 868 pp. (In French)

SASAl, P., Niquil, N., Bartoli, P. (1999): Community structure of digenean parasites of sparid and labrid fishes of the Mediterranean Sea: A new approach. Parasitology, 119: 635 - 648. DOI: 10.1017/ S0031182099005077

SURES, B. (2004): Environmental parasitology: relevancy of parasites in monitoring environmental pollution. Trends Parasitol., 20: 170 - 177. DOI: 10.1016/j.pt.2004.01.014

SuRES, B. (2008): Environmental parasitology. Interactions be- tween parasites and pollutants in the aquatic environment. Parasite, 15: 434 - 438. DOI: 10.1051/parasite/2008153434

Thomas, F., Cezilly, F., de Meeûs, T., Crivelli, A., Renaud, F. (1997): Parasitism and ecology of wetlands: a review. Estuaries, 20: $646-$ 654. DOI: $10.2307 / 1352622$

Thrush, S.F., Pridmore, R.D., Hewitt, J.E., Cummings, V.J. (1991): Impact of ray feeding disturbances on sandflat macrobenthos: do communities dominated by polychaetes or shellfish respond differently? Mar. Ecol. Prog. Ser., 69: 245 - 252. DOI: 10.3354/ meps069245

Valtonen, E.T., Holmes, J.C., Koskivaara, M. (1997): Eutrophication, pollution and fragmentation: effects on parasite communities in roach (Rutilus rutilus) and perch (Perca fluviatilis) in four lakes in central Finland. Can. J. Fish. Aquat. Sci., 54: 572 - 585. DOI: 10.1139/f96-306

VERLAQUE, M. (1990): Flore marine de la région de Galeria [Marine Flora of the Galeria Region]. Trav. Sci. Parc Nat. Rég. Réserves Nat. Corse, 29: 77 - 88 (In French)

Verlaque, M., Francour, P., Sartoretto, S. (1999): Evaluation de la valeur patrimoniale des biocénoses marines de la face ouest de l'îlot de Gargalu (Réserve intégrale de Scandola) [Evaluation of the heritage value of marine biocenoses of the western side of Gargalu islet (Scandola Reserve)]. Trav. Sci. Parc Nat. Rég. Réserves Nat. Corse, 59: 121 - 116 (In French) 